\title{
Technology for Social Inclusion: the Case of Electricity Access in the Brazilian Amazon
}

\author{
Maria F. Gómez , Alessandro Sanches-Pereira, Semida Silveira \\ Department of Energy Technology, Division of Energy and Climate Studies \\ KTH Royal Institute of Technology \\ e-mail: mfgg@kth.se
}

Cite as: Gomez, F. M., Sanches-Pereira, A., Silveira, S., Technology for social inclusion: the case of electricity access in the Brazilian Amazon, J. sustain. dev. energy water environ. syst., 1(3), pp 237-259, 2013, DOI:

http://dx.doi.org/10.13044/j.sdewes.2013.01.0018

\begin{abstract}
This paper explores the Social Technology concept and analyses how it can support the current Brazilian rural electrification initiative. It addresses the question: 'can Social Technology principles serve to identify concrete tasks to overcome the challenges of universal access in the Amazon? If so, how can they be effectively incorporated into the current Brazilian rural electrification initiative?' We conclude with the identification of two concrete actions to achieve universal access in isolated areas. First, the recognition, compilation and systematization of local knowledge are important tasks ahead. Second, effective communication channels and methods are needed to spread local knowledge and support the design, implementation, and operation of innovative solutions. Participatory activities are crucial to enable these concrete actions. We highlight the role of the government at central and local levels for the purpose of setting up the appropriate environment for these changes to happen.
\end{abstract}

\section{KEYWORDS}

Renewable Energy, Isolated Areas, Electricity Access, Social Technology, Social Inclusion, Causal Loop Diagram

\section{INTRODUCTION}

Electricity access is recognized as essential to achieve global development goals [1-3]. Yet, there are still significant disparities in the way electricity services are provided worldwide. Today, over 1.3 billion people lack electricity access. Most of them live in rural areas of developing countries [4]. Within this global context, national governments face serious challenges to extend electricity services: they need to adopt explicit electrification targets, allocate funds to achieve these targets, and define strategies for effectively delivering electricity services [4].

In pursuit of universal access, Brazil has developed a well-structured network operating at different levels, which has proven effective in electrifying communities through the extension of the grid. However, to reach dispersed populations in isolated areas of the Brazilian Amazon, where grid extension is not feasible, a different solution is required. About 930 thousand people are still without electricity services in the isolated areas within the region [5]. Off-grid technologies in place have seldom taken advantage of locally available energy sources. This has been the case, despite the strong emphasis that the Brazilian government has given to electrification as a driver for development in

\footnotetext{
* Corresponding author
} 
the past decade. At the moment, the number of diesel-based power plants with capacity less than $1 \mathrm{MW}$ installed in the Brazilian Amazon is more than ten times that of small scale hydro power plants, despite the abundant hydro potential available [6].

A number of initiatives have been launched in an effort to bridge the technological gap in the Brazilian Amazon using locally available resources (biomass, water sources and solar radiation) but they have not been systematically implemented [7]. A different model is required for the rural electrification initiative to be fully integrated in the development process of the Amazon region. Such a model should consider off-grid technologies for power generation and locally available resources [6, 8]. Previous experience has shown that the concept of Social Technology can provide a suitable framework to promote the required integration of agents, sources, and technology in the region [9].

In this paper, we explore the Social Technology concept as a framework to support the current Brazilian rural electrification initiative. The concept provides a different view on how the relationships between resources, technologies and institutions could evolve and promote social inclusion. Social inclusion is seen as the process by which society combats poverty and involuntary exclusion of individuals and groups from political, economic and societal processes [10]. The fact that achieving universal energy access has a significant impact on human development provides a starting point for our analysis [3, 11]. Can Social Technology principles serve to identify concrete tasks to overcome the challenges of universal access in the Amazon? If so, how can they be effectively incorporated into the current Brazilian rural electrification initiative? For the purpose of this analysis, we built a system based on (i) the reality of the Brazilian rural electrification initiative, (ii) the concept of social technology and, (iii) our perception on their interconnections. We use a Causal Loop Diagram (CLD) to visualize the system and analyse cause-and-effect relationships among elements.

The next section provides the background and challenges that the Brazilian government is facing in relation to universal access achievements in isolated areas of the Amazon. In Section 3 we explain the concept of Social Technology and its applicability within the Brazilian context. Section 4 illustrates the dynamics of the system based on the CLD. Finally, we conclude by identifying two concrete actions towards universalization in the Amazon.

\section{THE BACKGROUND AND CHALLENGES OF UNIVERSALIZATION IN THE BRAZILIAN AMAZON}

The Brazilian rural electrification program has been developed based on a rural electrification policy that is clearly related to social inclusion and development initiatives $[12,13]$. The program was designed and implemented based on a strong recognition of the role that electricity access can play in addressing and achieving development goals. This has been important for the mobilization of political will, definition of policies and allocation of resources to promote full electricity access. The interaction between implementing agents, citizens and well established institutions has been crucial for the materialization of the program. Citizens are considered as a part of the electrification process and not just the ultimate beneficiaries, which leads to the recognition of real needs and actual demand, better dimensioning of the system and a successful implementation [3].

In terms of technology, the rural electrification program has evolved based on the extension of the electricity network in Brazil, which is highly dependent on large scale hydropower plants. The program has achieved remarkable results in areas close to the grid, and more than 14 million people have been provided with electricity services 
throughout the country. However, the program faces significant challenges in isolated localities. While the Brazilian rural electrification initiative has created a strong base to effectively provide electricity to non-isolated areas, it still needs to be adjusted in terms of technology and institutions to operate in the context of remote areas of the Amazon region.

Concessionaires, the main providers of electricity in the country, are required to fully supply electricity services to citizens living in their concession area, guaranteeing low tariffs for low-income population $[12,13]$. The view of the Brazilian government is that poor households cannot afford electricity access if subsidies are not offered. As a result, there is a strong subsidy scheme in place that combines connection and consumption subsidies. The government provides financial support to the concessionaires in the form of grants and soft loans, and the concessionaires are expected to pass the resources on to the end users in the form of free connections or lower tariffs, once the end user is provided with electricity services. While connection subsidies are one-off benefits that eliminate the price customers pay to connect to the system, consumption subsidies incorporate quantity targets as they operate through the tariff structure as a percentage discount applied to final residential users' bills. Yet, subsidies in place have not been enough to motivate innovative solutions for rural and remote areas.

Concessionaires have not been as crucial for the development of the rural electrification program in isolated areas as they have been in urban and peri-urban areas. In Brazil, 99\% of households are provided with electricity services by concessionaires. In the Amazon region, concessionaires supply electricity services to only $62 \%$ of the rural households, or about 2.4 million people, through centralized and large-scale systems (see Figure 1). About $14 \%$ of the rural population of the region, or around 500 thousand people, are supplied through other kinds of organizations using stand-alone or mini-grids, mainly diesel-based, and 24\%, or about 930 thousand people, are not supplied at all [5].

\begin{tabular}{|c|c|c|c|}
\hline $\begin{array}{l}24.1 \% \\
\text { Ruralhouseholds } \\
\text { in the Amazon region }\end{array}$ & $\begin{array}{l}14.4 \% \\
\text { Rural households } \\
\text { in the Amazon region }\end{array}$ & \multicolumn{2}{|c|}{$\begin{array}{l}\quad 61.5 \% \\
\text { Ruralhouseholds } \\
\text { in the Amazon region }\end{array}$} \\
\hline \multicolumn{2}{|c|}{ Decentralized systems } & \multicolumn{2}{|c|}{ Centralized systems } \\
\hline Nonexistent & Off-grid systems & \multirow[b]{2}{*}{ Local grids } & \multirow[b]{2}{*}{ Interconnected Grid } \\
\hline $\begin{array}{l}\text { Communities without } \\
\text { electricity access }\end{array}$ & $\begin{array}{l}\text { Communities with electricity } \\
\text { access provided by stand- } \\
\text { alone systems or mini-grids }\end{array}$ & & \\
\hline
\end{tabular}

Figure 1. Present electricity access coverage in the Amazon region Adapted from Gómez [7]

A group of new organizations have emerged to supply electricity to isolated communities. Generally, these organizations operate off-grid diesel-based systems during 4 to 5 hours per day, which provide electricity services that do not fulfil national standards [14]. In contrast to concessionaires, a number of decentralized organizations are not officially included in the Brazilian power system. While concessionaires are integrated into the rural electrification program and have access to financial resources in the form of subsidies or soft loans, decentralized organizations are not officially recognized and lack financial support from the Federal government [7].

The situation has created inefficiency in the provision of electricity to rural and isolated areas. Decentralized organizations co-exist with concessionaires within a context 
in which a lack of rules prevents the delivery of reliable electricity services. Neither concessionaires nor existing decentralized organizations have proved effective in achieving universal electricity access in the Amazon region. There is a clear deficiency in the implementation, operation, and monitoring processes of off-grid systems and this has prevented the achievement of universal electricity access in the Amazon region. Thus, to achieve universal access in the Amazon, it is necessary to adapt existing delivery structures to appreciate the conditions and specific needs of the rural population in the region [7].

The Brazilian Amazon region ${ }^{1}$ is characterized by a very low population density, that is, about 4 inhabitants per square kilometre in comparison with a national population density of about 22 inhabitants per square kilometre. This highly dispersed population is also characterized by a very low income. These factors together with a complicated topography impose a significant challenge, which entails the need for different technologies to provide electricity in the area [6]. Within this context, the natural question is how to meet the targets of universal electricity access in isolated areas?

It is recognized that renewable technologies can provide increased electricity access in isolated areas of the region [15]. Yet, neither locally and widely available renewable sources nor off-grid technologies have been systematically explored in the Brazilian Amazon. Technologies such as solar photovoltaic, wind power, small hydropower and biodiesel power plants remain as interesting alternatives to be further explored in isolated communities in the region [16-20]. How contributions from renewable energy technologies can specifically support the provision of electricity access and facilitate development in the region at the same time, as stated in governmental goals, is still a subject of discussion.

\section{SOCIAL TECHNOLOGY: AN INNOVATIVE PERSPECTIVE AND ITS APPLICABILITY TO THE BRAZILIAN CONTEXT}

Social Technology has been used in different scenes for different purposes since the end of the 19th century but remains a somewhat elusive concept. Henderson (1901) defined social technology as a system or mechanism adapted to promote the interests of a group in harmony with the interests of a whole community [21]. More recently, and according to the Social Technology Institute (ITS), social technology has been defined as a "range of transforming techniques and methodologies which are developed and/or applied in interaction with communities and absorbed by them, resulting in social inclusion and improvement of quality of life" [22]. Social technology is also defined by the Brazilian Social Technology Network (RTS) ${ }^{2}$ as "products, techniques and/or replicable methodologies, developed in interaction with the community and representing effective solutions for social transformation" [23].

Though the Social Technology movement is a recent initiative, it corresponds to an evolution of the Appropriate Technology Movement (ATM) originally created by Schumacher [24], drawing upon foundations laid by Gandhi and others. Schumacher argued that only labour-intensive and small-scale technologies could, in a context of poverty, enhance economic development. He also argued that these technologies should be evaluated in terms of its contribution to a process of production and should be

\footnotetext{
${ }^{1}$ The Amazon region is here defined as equivalent to the North region in the official macro-region division of the country. Although the Amazon region can be defined in different ways, the direct association between the Amazon and the North region has been a common practice in various studies on the region.

${ }^{2}$ The Brazilian Social Technology Network (RTS) was created in 2005 and aims to contribute to the promotion of social inclusion in public policy development through technology solutions aiming at sustainable development.
} 
beneficial to its users and to the society at large. Schumacher envisioned intermediate technologies as being significantly more productive than the indigenous technology and significantly cheaper than the sophisticated, highly capital-intensive technology of modern industry [24]. The ATM is a well-recognized movement which is related to an extensive network of organizations and implemented projects. It has often been associated with community development. For example, as cited by Akubue [25], ATM is a "complete systems approach to development that is both self-adaptive and dynamic, because as its users become wealthier and more skilled, they can both afford and also use more expensive technical means". In 1984, information on more than 300 organizations working on the implementation and diffusion of appropriate technologies in developing and in industrialized economies was compiled and organized in a Directory by Jéquier, $\mathrm{N}$. and Blanc, G. [26].

The ATM peaked in the 1970s. However, it was during the end of the 1980s that the movement started to decline in prominence and only few groups survived until the 2000s [27]. One example of these organizations is the Intermediate Technology Development Group (ITDG), founded by Schumacher and colleagues in 1966 and now called Practical Action, which today still provides systematized information related to intermediate technologies [28]. One possible reason for the decline of the ATM is related to a shortcoming in Schumacher's framework: the implementation of appropriate technologies required active participation from actors who should systematically apply new ideas to production rather than producing by acquiring the technology from others. Yet, appropriate technologies struggled to induce innovation dynamics and capabilities beyond the solution of basic needs and specific production problems [27, 29]. As a result, new movements such as Social Technology emerged.

In general, Social Technology implies thinking and developing technologies, from design to implementation, considering social inclusion goals. As a result, the implementation of social technologies creates significant social impacts, particularly important for less developed regions. In this sense, social technology conveys a conceptual framework that incorporates multidisciplinary cooperation, local resources, and knowledge to the implementation of off-grid technologies.

The concept of Social Technology incorporates a new way of conceiving technology in which active participation of a number of agents such as the state, the community, the academia and social movements are crucial. It recognizes that different actors can propose different methods to implement such systems depending on the context in which they evolve. In this sense, technology cannot be thought of as simple equipment that is designed in one place by some actors and implemented in another by other agents. Alternatively, technologies should be designed and implemented considering processes developed at the place where they will be used and by the actors who will use it [30]. This creates a positive impact at local level in terms of technology uses, resources utilization and social dynamics. Social Technology is not normative. Instead, it emphasizes the relevance of diverse methodologies or paths that can be followed in order to set up technology systems which are locally planned and implemented. In this sense, Social Technology encompasses four main dimensions (See Figure 2): (i) Technology, (ii) Local Knowledge, (iii) Society and Environment, and (iv) Participatory Processes [31, 32].

The Brazilian Institute of Social Technology (ITS) highlights the relevance of considering these dimensions from planning to implementation and evaluation of a technology [33]. But the recognition of these dimensions implies a strong commitment to social transformation and environment protection and the need for organizing and 
systematizing local knowledge, implementing accessible and appropriate technologies, and permanently relying on participatory processes that involve all stakeholders.

It is important to emphasize that technology design, planning, implementation and evaluation are not neutral processes. They imply a number of socio-environmental impacts that need to be assessed. Notice that, as represented in Figure 2, the dimensions of Local Knowledge and Society and Environment are essential for implementing successful social technologies. If these dimensions are not considered, the system collapses. At the same time, these dimensions are connected by strong linkages that are often disregarded. For example, the implementation of an off-grid technology such as a small-scale biodiesel power plant to provide electricity services has implications in terms of local knowledge as it involves collecting local seeds that have diverse uses - well known by local communities - that can adversely affect the ecosystem if not properly collected and considered from the beginning of the process. However, the same seeds can provide a new income source if they are used to produce not only electricity services but also final products such as essential oils highly appreciated in the market. In this case, a complementary technology to extract oil and a new design are required. For that, Participatory Processes - another key dimension of Social Technology - are instrumental as they motivate not only knowledge-building based on local acquaintance but also autonomous decision-making process. Clearly, the absence of one of the identified dimensions implies a failure in the materialization of the Social Technology concept.

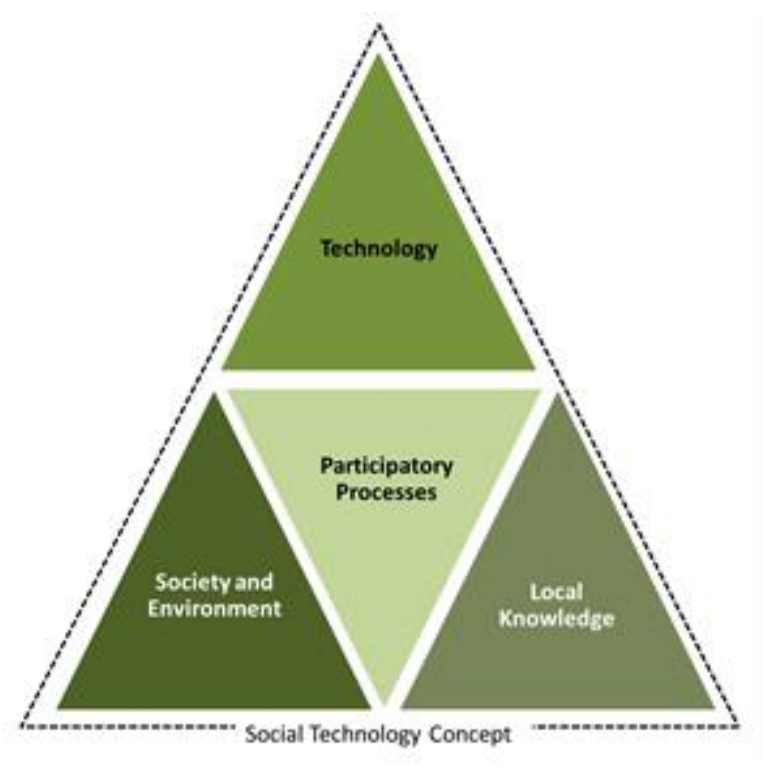

Figure 2. Dimensions encompassed by the concept of Social Technology

In addition, Social Technology implementation requires continuous and active participation from governmental institutions and other social agents such as communities, Non-governmental Organizations (NGOs), cooperatives and universities. In general, public and private sectors play a role and potential solutions can result in the adaptation or creation of technologies according to communities' interests, in an autonomous process [30]. Accordingly, communities are seen as essential actors who should take part in the process of promoting their own projects through identification of their energy needs and active participation in decision-making processes.

Social Technology also implies accessibility and appropriation of diverse technologies. On the one hand, accessibility is about ensuring a technology that can be 
used by the rural communities. Low cost and low complexity, though not indispensable, are factors that can facilitate access. On the other hand, appropriation is understood as the process through which communities incorporate new aspects to their knowledge base including the social connotation of a technology.

In Brazil, the Social Technology movement has gained importance through institutions such as the Brazilian Reference Centre on Social Technology (CBRTS) ${ }^{3}$ and the Foundation Bank of Brazil (FBB). The latter has played a key role in the enhancement of social technologies through the mobilization of NGOs, universities, state governments, municipalities, foundations and institutes throughout the country. FFB aims at identifying, certifying, rewarding and disseminating social technologies which are already implemented at the local, regional or national level and are effective in addressing issues related to food, education, energy, housing, environment, water resources, income and health [34]. The Foundation created the Bank of Social Technologies (BTS) to have a record of successful solutions in diverse areas.

In addition, ITS has identified the main implications of social technologies in connection with each key dimension. These implications help the understanding of the concept and its practical application. They are also the foundation of a Monitoring System of Social Technologies (Satecs) ${ }^{4}$ that has been used in Brazil to follow up diverse social technology projects in the complex context of Brazilian communities [22]. Table 1 summarizes the rationale behind each of the implications which we use to analyse the potential of social technologies to overcome identified shortcomings in the Brazilian rural electrification initiative [31, 32].

In essence, the concept of Social Technology is based on a strong commitment towards social inclusion. The recognition of the social technologies as drivers for social inclusion and communities' development is one of the reasons why they are frequently related to small-scale and productive applications, the latter being mainly directed towards the local market and having the potential to enhance the creativity of local producers [30]. This is particularly important for electricity access programs since it provides a way for ensuring the sustainability of rural electrification projects through income generation activities that can help to cover the cost of the provided services. For example, BTS has promoted the dissemination of knowledge and experiences that have a positive social impact. Specifically in the field of energy, there are already a number of initiatives throughout Brazil [9]. One of them is implemented in Fortaleza. In this city, limited and expensive access to electricity services created the need for a reliable energy supply system to produce high quality fruits and vegetables and improve irrigation practices. The use of a solar-energy based technology for production of fruits and vegetables has resulted not only in reduced electricity consumption but also in a more rational use of land in the area. Farmers were trained in the techniques of irrigation and finally they obtained an increased production and family income, diversified crops, and improved health. Rural exodus was also reduced. To achieve such results, free flow of information, an atmosphere of cooperation, and effective community participation in planning, monitoring and evaluation were promoted through the implementation of the social technology concept $[30,35]$. Surprisingly, there is just one implemented social

\footnotetext{
${ }^{3}$ The CBRTS is a project of the Institute of Social Technology (ITS), which opened in May 2004 through a partnership with the Department for Social Inclusion, Ministry of Science and Technology.

${ }^{4}$ The ITS has compiled a number of experiences of Social Technology in diverse fields such as family farming and small and medium enterprises related to textile and food production. Information on these experiences is available in the web-page: http://www.itsbrasil.org.br/ . According to ITS' official figures, the number of beneficiaries of Social Technology projects developed between 2006 and 2010 is about 875 thousand.
} 
technology (a solar wood-drying system) in the Brazilian Amazon [9]. This indicates a major potential for social technologies implementation in the region.

Experiences on the application of Social Technology concept have shown that harmonization with the regional context implies considering not only local resources and realities but also the integration of various members of the society in the design, implementation and operation of small-scale technologies [9].

Table 1. Dimensions and Implications of Social Technology

\begin{tabular}{|c|c|c|}
\hline Dimension & Implication & Rationale \\
\hline \multirow[t]{4}{*}{$\begin{array}{l}\text { Society and } \\
\text { environment }\end{array}$} & Commitment to social transformation & $\begin{array}{l}\text { Recognition of the need for a social transformation } \\
\text { is central to implement Social Technology. The process } \\
\text { implies active participation from national, regional and } \\
\text { local governments but other social actors such as } \\
\text { communities, NGOs, cooperatives and universities must } \\
\text { be involved and aware of their role. }\end{array}$ \\
\hline & Recognition of societal needs & $\begin{array}{l}\text { The starting point for the implementation of Social } \\
\text { Technology is the identification of communities' needs. } \\
\text { Participatory mechanisms are crucial for this purpose. }\end{array}$ \\
\hline & Social relevance and effectiveness & $\begin{array}{l}\text { Technologies are valued by their power to provide a } \\
\text { better quality of life rather than by their sophistication } \\
\text { level. }\end{array}$ \\
\hline & Sustainability & $\begin{array}{l}\text { Environmental, social, and economic impact } \\
\text { evaluation are integrated with the development and } \\
\text { implementation of Social Technology. }\end{array}$ \\
\hline \multirow[t]{2}{*}{ Technology } & Organization and systematization & $\begin{array}{l}\text { Social Technology is linked to the definition of } \\
\text { innovation, not necessarily in the sense of sophisticated } \\
\text { technology but in the sense of technology having a } \\
\text { significant impact on quality of life. } \\
\text { Social Technology is multidisciplinary. Precision, } \\
\text { clarity and systematization of methods facilitates } \\
\text { understanding actions from multiple stakeholders. }\end{array}$ \\
\hline & $\begin{array}{l}\text { Accessibility and appropriation of } \\
\text { technologies }\end{array}$ & $\begin{array}{l}\text { Social Technology implies accessibility and } \\
\text { ownership of technologies. Low cost, though not } \\
\text { indispensable, facilitates access. Accessibility can also } \\
\text { be increased as appropriation is promoted. Appropriation } \\
\text { is understood as the process through which communities } \\
\text { understand not only the technical aspects but also the } \\
\text { social implications of a technology. }\end{array}$ \\
\hline \multirow[t]{3}{*}{ Knowledge } & Educational processes & $\begin{array}{l}\text { All stakeholders are involved in an educational } \\
\text { process in which knowledge is built on a specific reality } \\
\text { and diverse interactions. The ultimate goal is to create } \\
\text { autonomous communities. }\end{array}$ \\
\hline & Diverse knowledge & $\begin{array}{l}\text { Social Technology enhances the diffusion of } \\
\text { specific knowledge of the diverse stakeholders. Local } \\
\text { knowledge cannot be ignored. Instead, it can } \\
\text { complement (and be complemented by) knowledge } \\
\text { based on other stakeholders. }\end{array}$ \\
\hline & Diffusion and educational activities & $\begin{array}{l}\text { The diffusion of the concept of Social Technology } \\
\text { and its implications consolidates and strengthens } \\
\text { development actions. Qualified public debate should be } \\
\text { promoted through established communication channels. }\end{array}$ \\
\hline $\begin{array}{l}\text { Participatory } \\
\text { processes }\end{array}$ & $\begin{array}{l}\text { Democratic processes are built } \\
\text { through participatory practices. }\end{array}$ & $\begin{array}{l}\text { Participatory schemes are critical to developing } \\
\text { ownership and facilitating knowledge building amongst } \\
\text { stakeholder groups. These processes engage all } \\
\text { stakeholders in determining their own development. } \\
\text { Democratic and participatory practices are crucial to } \\
\text { promote sustainable development. }\end{array}$ \\
\hline
\end{tabular}

Sources: $[31,32]$ 


\section{ELECTRICITY ACCESS AND SOCIAL TECHNOLOGY: THE DYNAMICS OF THE SYSTEM}

This section introduces a system in which the reality of the rural electrification initiative in Brazil is combined with our perception on Social Technology principles in order to propose concrete actions to achieve universalization in the country. We understand a system as a set of elements that satisfy three conditions: i) the behaviour of each element has an effect on the behaviour of the whole; ii) the behaviour of the elements and their effect on the whole are interdependent and iii) elements of the system are so connected that independent sub-groups of them cannot be formed [36]. In this case, we built a system based on elements of the Brazilian rural electrification program which are already in place and combined them with key elements of the Social Technology concept. In this system, the actual gap in electricity access reinforces the need for improved institutions (i.e. NGOs, concessionaires, etc.) and a better use of energy resources and technologies to effectively implement rural electrification projects in isolated areas.

\section{The Causal Loop Diagram}

The Causal Loop Diagram (CLD) is an analytical tool used in system dynamics to develop understanding and facilitate the analysis of complex systems. The CLD helps to visualize the system and analyse cause-effect relationships among elements. In this way, it enables the identification of potential actions to modify the system in order to achieve desired goals [37].

One advantage of the CLD is that it illustrates interactions that are difficult to verbally describe such as circular chains of cause-and-effect [38]. While CLDs cannot be used as a conceptualizing tool because they lack organizing power required to represent decision-making processes, they can be used as an analytical tool to provide an overview of a given system's behaviour [39]. CLD is thus an important tool to: (i) capture the structure of a system, (ii) provide an overview of loop configurations to analyse the system behaviour, and (iii) communicate important feedbacks claimed to have the potential to solve an identified problem [39, 40]. For the purpose of this analysis, we built a system based on (i) the reality of the Brazilian rural electrification initiative; (ii) the concept of social technology and, (iii) our perception on their interconnections. Figure 3 shows the resulting CLD. Components in blue correspond to key elements of the rural electrification program which are already in place. Components in red illustrate key elements of the Social Technology concept.

The Brazilian rural electrification policy has a strong orientation towards social inclusion (Element Social Inclusion) and has relied on a highly subsidized scheme that includes both connection (Element Connection subsidies) and consumption subsidies (Element Consumption subsidies). The highly centralized rural electrification program has successfully used the concession model to provide electricity to more than 14 million inhabitants but there is an identified need for adapting the existing institutional structures on the implementation side (Element Implementing Institutions) and promoting local resource-based technologies (Element Energy Technology) and resources (Element Energy Resources) to appreciate the conditions and specific needs of the rural and isolated population in the Amazon [3, 6]. 


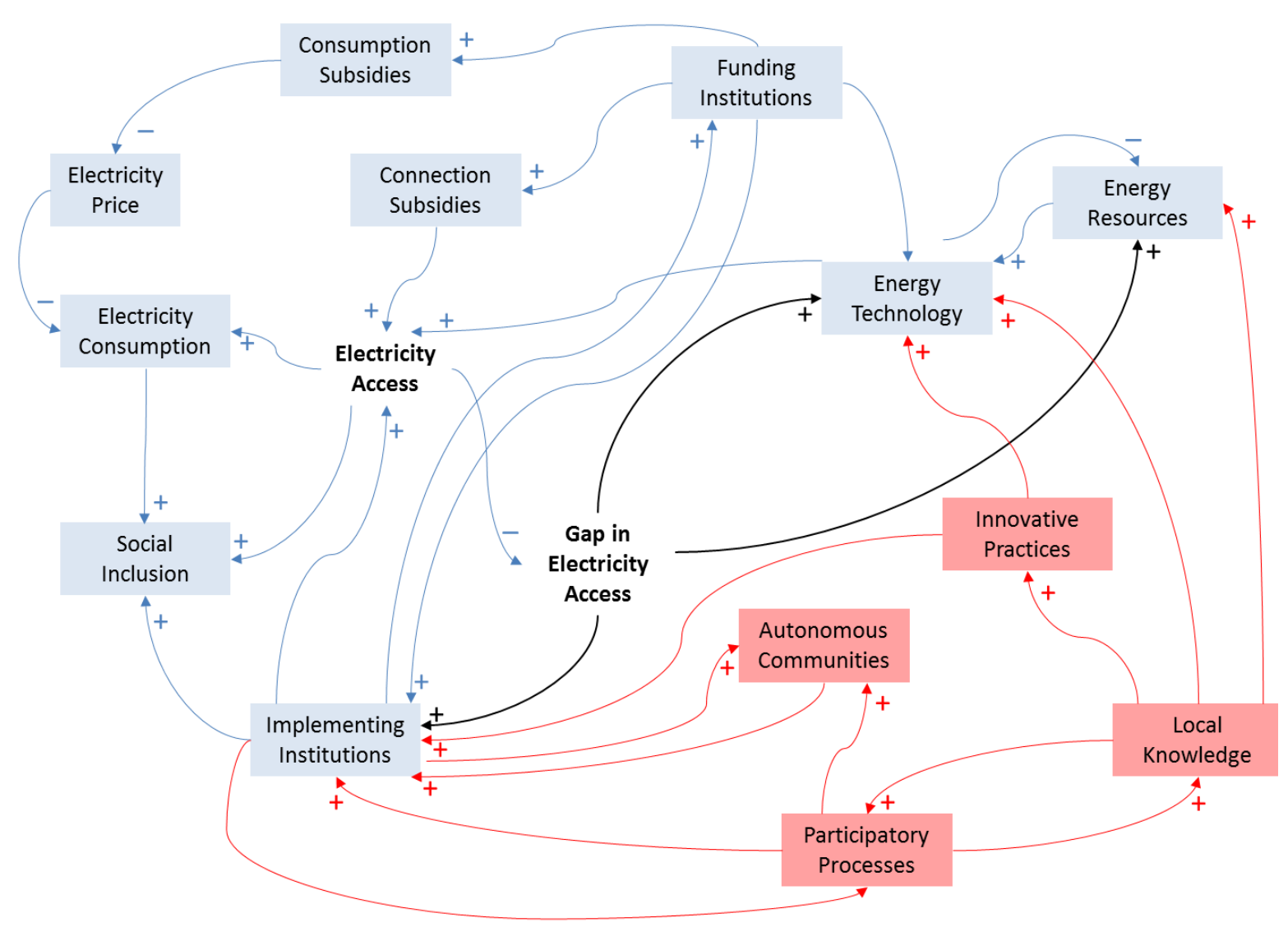

Figure 3. Causal Loop Diagram for the Brazilian rural electrification System

\section{Causal Links}

Causal links indicate how elements interact with each other within a system. They are illustrated by unidirectional arrows and complemented with positive or negative signs. A positive sign indicates a reinforcing effect, in which a change in the element " $X$ " produces a change in element " $Y$ " in the same direction. Meaning, an increment in "X" implies an increment in " $Y$ " or a reduction in " $X$ " implies a decrease in "Y". In contrast, a negative sign shows a balancing effect, in which a change in " $\mathrm{X}$ " produces a change in " $Y$ " in the opposite direction. Meaning, " $Y$ " decreases if " $X$ " increases and vice-versa. Thus, interactions between the elements can create balancing $(-)$ or reinforcing $(+)$ effects $[38,41]$. For example, an increase in Electricity Access is directly related to an improvement in Social Inclusion, which illustrates a reinforcing effect. On the other hand, a reduction in Electricity Price is directly related to an increase of Electricity Consumption, which illustrates a balancing effect. It is important to observe that arrows imply direction of causation and not a time sequence, in which a causal link connecting " $\mathrm{X}$ " to " $\mathrm{Y}$ " means that when " $X$ " increases, so does " $Y$ " instead of something needs to happen first on " $X$ " before having an effect on "Y" $[36,38]$.

\section{Balancing and reinforcing causal loops}

Once the elements of the system are recognized, and the positive or negative connections are allocated to each element, a number of balancing and reinforcing loops can be identified. Consider for example, the Gap in Electricity Access element presented in Figure 3. This element enforces the need for Implementing Institutions and, continuing in 
the diagram, we see that Implementing Institutions influences Electricity Access which in turn influences Gap in electricity access. In this way the element Gap in electricity access influences itself, creating a feedback loop or a causal loop.

Causal loops can be either balancing or reinforcing. Balancing loops, as it is the case of the example just described, are associated with solving a problem or achieving a goal. It is important to mention that balancing loops can be very powerful and create a system averse to changes and a quite rigid structure. Balancing loops provide stability to a system regulating its dynamics. In reinforcing loops, the interactions are such that each action adds to the other. These loops are important because they can lead to growth or decay of the system at an ever-increasing rate in a reinforcing process similar to snow balls rolling downhill. However, they can be misleading as they can be perceived as a slow process during its early stages of development, but then their growth speeds up exponentially. As a result, reinforcing loops can lead to late reactions and ineffective decision-making processes [38]. Figure 3 also provides an example of a reinforcing loop. Consider the Implementing Institutions element. We see in the diagram that this element influences Participatory processes. Thus, there is a causal link that indicates that Implementing Institutions are associated to the development of Participatory Processes. We also see that Participatory Processes influences Autonomous Communities, which in turn influences Implementing Institutions. In this way, the diagram has served to illustrate and identify a reinforcing causal loop in which Participatory Processes influence positively Implementing Institutions via Autonomous Communities.

The analysis of the CLD shown in Figure 3 provided 15 causal loops of which nine are balancing and six are reinforcing loops. Each causal loop is made up from two up to seven elements. In order to simplify the number of causal loops being presented in Table 2, smaller balancing and reinforcing loops were omitted and used only to provide information to enrich the discussion. For balancing loops, four small loops containing between two and four elements were omitted. In the case of reinforcing loops, four small loops containing less than three elements were omitted.

Table 2 shows selected balancing and reinforcing loops. They are grouped into three categories according to their influence on elements initially foreseen as having the potential to bridge the gap in electricity access. These key elements are shown in Figure 3: implementing institutions, energy resources and energy technologies. Balancing loops considering Implementing and Funding Institutions were grouped under the category Institutions. There was only one balancing loop considering Energy Resources which was assigned to the category with the same name. Balancing loops including Energy Technology were also clustered under a category with the same name (Energy Technology). Finally, reinforcing loops were aggregated under the category Institutions.

Figure 4 illustrates the first category within balancing forces in our system. The figure comprises two balancing loops. Note that none of the elements covered by Social Technology appears in the figure as it shows only elements considering the reality of the Brazilian rural electrification initiative, indicated in blue. Figure 4 also shows how Implementing and Funding institutions are interconnected in order to achieve national electricity access goals. In Brazil, the main implementing institutions within the rural electrification program are the concessionaires. They have been instrumental to develop rural electrification projects. The Brazilian government provides financial support to concessionaires in the form of grants and soft loans, and concessionaires are expected to pass the resources on to the end users in the form of connection subsidies or lower tariffs, once the end user is provided with electricity services. Funding institutions includes federal government, state governments and concessionaires who are expected to provide about $75 \%, 10 \%$ and $15 \%$ of the required funds respectively [7]. 
Table 2. Balancing and reinforcing forces within the Brazilian rural electrification system

\begin{tabular}{|c|c|}
\hline & Balancing Forces \\
\hline \multirow[t]{2}{*}{ Institutions } & $\begin{array}{l}\text { 1. Electricity access } \rightarrow(-) \text { Gap in electricity access } \rightarrow(+) \text { Implementing } \\
\text { Institutions } \rightarrow(+) \text { Funding Institutions }(+) \text { Energy Technology } \rightarrow(+) \\
\text { Electricity Access }\end{array}$ \\
\hline & $\begin{array}{l}\text { 2. Electricity access } \rightarrow(-) \text { Gap in electricity access } \rightarrow(+) \text { Implementing } \\
\text { Institutions } \rightarrow(+) \text { Funding Institutions }(+) \text { Consumption Subsidies } \rightarrow \\
(+) \text { Electricity Access }\end{array}$ \\
\hline $\begin{array}{l}\text { Energy } \\
\text { Resources }\end{array}$ & $\begin{array}{l}\text { 3. Electricity access } \rightarrow(-) \text { Gap in electricity access } \rightarrow(+) \text { Implementing } \\
\text { Institutions } \rightarrow(+) \text { Participatory Processes }(+) \text { Local Knowledge } \rightarrow(+) \\
\text { Energy resources } \rightarrow(+) \text { Energy Technology } \rightarrow(+) \text { Electricity Access }\end{array}$ \\
\hline \multirow[t]{3}{*}{$\begin{array}{l}\text { Energy } \\
\text { Technology }\end{array}$} & $\begin{array}{l}\text { 4. Electricity access } \rightarrow(-) \text { Gap in electricity access } \rightarrow(+) \text { Implementing } \\
\text { Institutions } \rightarrow(+) \text { Participatory Processes }(+) \rightarrow \text { Local Knowledge } \rightarrow \\
(+) \text { Innovative Practices } \rightarrow(+) \text { Energy Technology } \rightarrow(+) \text { Electricity } \\
\text { Access }\end{array}$ \\
\hline & $\begin{array}{l}\text { 5. Electricity access } \rightarrow(-) \text { Gap in electricity access } \rightarrow(+) \text { Implementing } \\
\text { Institutions } \rightarrow(+) \text { Participatory Processes }(+) \text { Local Knowledge } \rightarrow(+) \\
\text { Energy Technology } \rightarrow(+) \text { Electricity Access }\end{array}$ \\
\hline & Reinforcing Forces \\
\hline \multirow[t]{2}{*}{ Institutions } & $\begin{array}{l}\text { 6. Implementing Institutions } \rightarrow(+) \text { Participatory Processes (+) Local } \\
\text { Knowledge } \rightarrow(+) \text { Innovative practices } \rightarrow(+) \text { Implementing } \\
\text { Institutions }\end{array}$ \\
\hline & $\begin{array}{l}\text { 7. Implementing Institutions } \rightarrow(+) \text { Participatory Processes }(+) \\
\text { Autonomous communities } \rightarrow(+) \text { Implementing Institutions }\end{array}$ \\
\hline
\end{tabular}

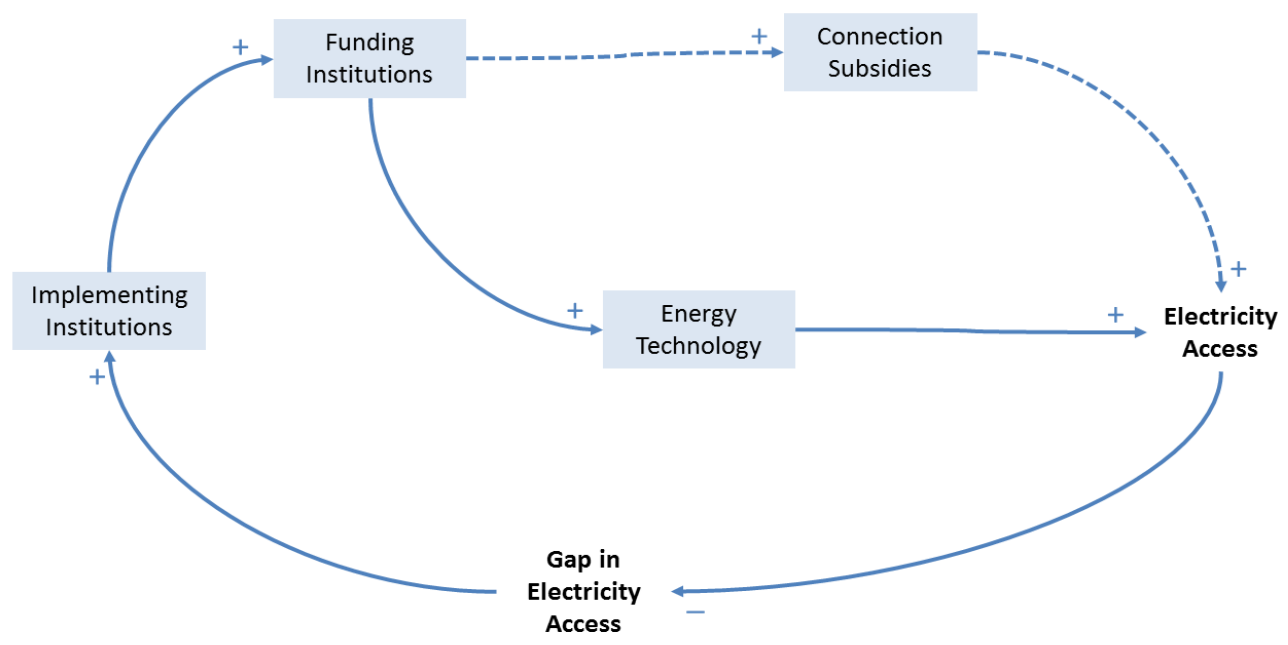

Figure 4. Balancing Forces corresponding to the category Institutions 
In short, Figure 4 shows the direct connection between Funding Institutions and Energy Technology to provide electricity access. In fact, the Brazilian government has allocated significant resources that have mainly assisted the extension of the grid. We have already mentioned that this specific technology has enabled the provision of electricity to more than 14 million people in the country and that concessionaires have acted as the main implementing institutions. Yet, because their action is driven by the size of the gap in electricity access, there is a natural tendency for concessionaires' action to decline as the desired goal is closer to its fulfilment. This tendency accounts for the fact that as projects approach completion it seems to be more and more difficult to make progress towards accomplishment. To compensate this tendency, the motivation for action should come from loops that are not directly connected to the gap [42]. Such is the case of isolated areas, where the "last mile" paradox gains importance and adds to the uniqueness of the region in increasing challenges for universalization. Thus, this loop provides valuable information as it confirms key achievements of the actual rural electrification initiative and promotes the exploration of new loops in search for concrete actions towards universal access in the Amazon.

The second category within balancing forces in the system corresponds to energy resources and it is illustrated in Figure 5. This loop provides new information as it includes two important elements of the Social Technology concept, Local Knowledge and Participatory Processes, and connects them to Energy Resources within the context of the actual Brazilian rural electrification initiative. In Brazil, the national electricity system has a strong dependency on hydro power resources which are widely available in the country. The interconnected national network comprises more than 89 thousand kilometres of transmission lines connected to $97 \%$ of the national installed power generation capacity. This system partially provides electricity to the Amazon region. The region is mainly supplied through local large-scale diesel-based systems that are not linked to the national interconnected network but that have served as the basis for further grid extension to electrify peripheral areas under a centralized scheme. Actions taken to promote the extension of the grid have promoted a decrease in the electricity access gap. However, there are limits to the growth of the grid imposed not only by economic factors but also by natural barriers and particular topography in isolated areas. The figure shows a reinforcing connection between energy technologies and resources in which the use of different Energy Resources is directly connected to an increase in the types of Energy Technologies that are required to provide electricity access. While the actual rural electrification program has given priority to the grid-extension and, consequently, has supported large-scale technologies, Social Technology stands for small-scale technologies based on local resources. The large variety of renewable resources in the Amazon could be harnessed by a number of small scale renewable technologies which are already well established in other parts of the country. But knowledge on those resources is required to effectively implement small-scale power generation projects.

Figure 5 shows that Local Knowledge can be reinforced through participatory processes which can in turn be influenced by Implementing Institutions. Having a strong presence in the region, implementing institutions such as concessionaires can play a significant role in the development of community-based projects. Yet, their actions need to be complemented by new agents and innovative practices as suggested by Social Technology principles. It is important to mention that information provided by Figure 5 needs to be complemented with new elements shown in Figure 6 to build a deeper understanding of the system. 


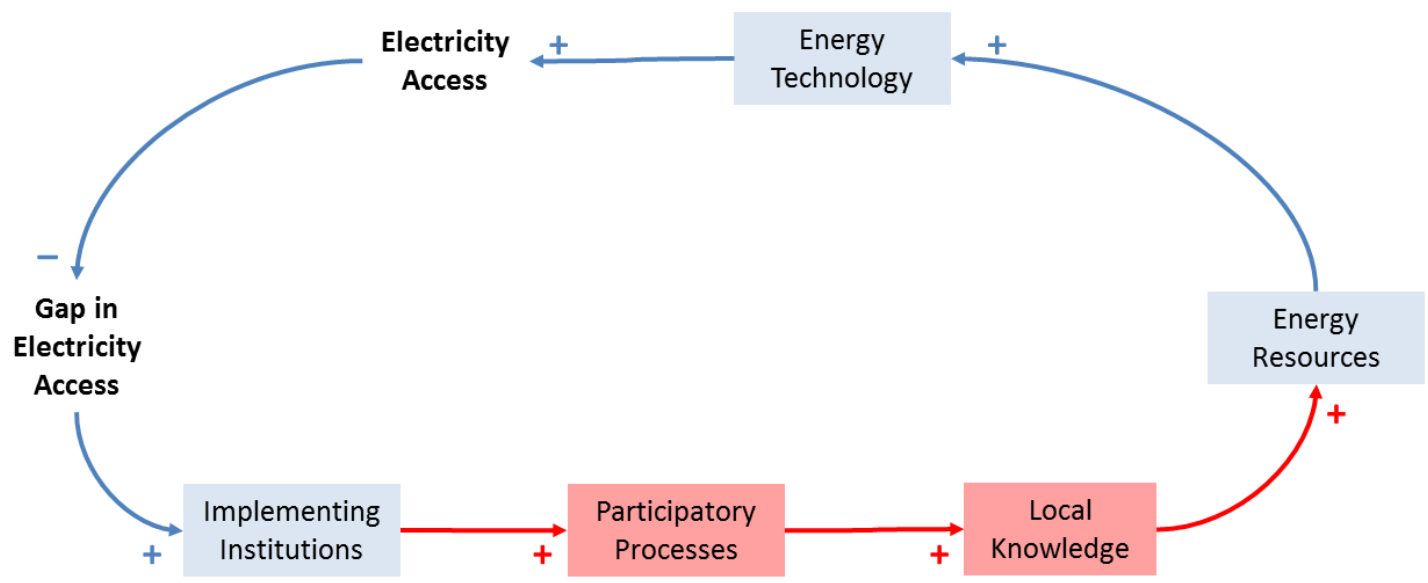

Figure 5. Balancing force corresponding to the category Energy Resources

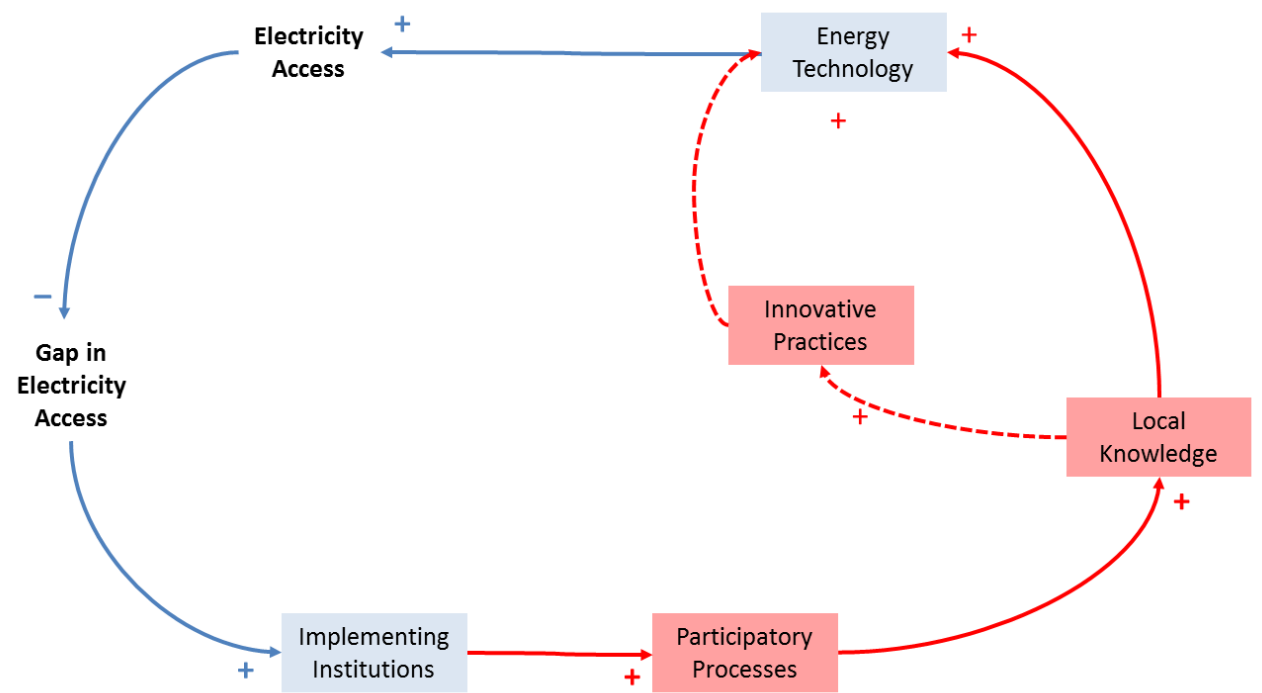

Figure 6. Balancing force corresponding to category Energy Technology

Figure 6 illustrates balancing forces corresponding to the category Energy Technology. This figure adds another key element of Social Technology: Innovative Practices. It shows that forces to promote Local Knowledge can have either a direct effect or an indirect effect, via Innovative Practices on Energy Technologies. It is important to state that, for the purpose of our analysis, local knowledge includes (i) traditional knowledge which is based on local communities and (ii) technical, expert, or academic knowledge which is based on research institutes, technology developers, NGOs and other specialized institutions acting in the region.

On the one hand, significant knowledge of renewable resources and their use which is needed to implement certain energy technologies is in the hands of local communities and is the result of ancient traditions. At the same time, local agents such as universities have precious information on the potential of new technologies for particular locations. Concessionaires, cooperatives and NGOs who have been active in the area have knowledge on energy consumption patterns of some communities living in isolated areas. This local knowledge can have a direct impact on the implementation of adapted small-scale renewable energy technologies based on local resources that are often 
unknown to outsiders. On the other hand, agents such as private entrepreneurs who are already interested in the region, but have not been formally involved in the rural electrification initiative, have knowledge not only on the technical implementation of specific technologies but also on the implementation of models that have proven able to provide electricity access in isolated areas. They can provide opportunities to accelerate electricity access through innovative practices. It is clear that in any case, a participatory process is required to channel existent knowledge towards effective implementation of energy technologies to provide electricity access.

In contrast with the centralized grid extension model, small-scale technologies are capable of harnessing a large variety of renewable resources which are available in the Amazon. At the same time, these technologies could protect the sensitive ecosystem by reducing harmful greenhouse gas emissions that originated in the current diesel-based model. The recognition of the need for this type of technologies is not new. A study conducted by the Global Network on Energy for Sustainable Development (GNESD) identified renewable based technologies providing off-grid electricity as having a significant potential for poverty alleviation contrasting with the traditional centralized grid-based systems [1]. In Brazil, the national government has already included the implementation of off-grid renewable-energy based technologies in its updated plan for rural electrification in isolated areas [15]. Thus, it is generally accepted that the implementation of these technologies has the potential to not only facilitate specific electricity access solutions in the form of small-scale, off-grid and renewable-energy-based power generation systems but also allow universalization goals in the region.

Though not fully quantified and characterized, a number of opportunities have been already identified and there is a number of technologies that are being tested in the Amazon region in the form of pilot projects. These projects have been promoted by governmental and research institutes, with participation from concessionaires and communities and are still under evaluation [6]. This shows a significant improvement on the way towards universalization in isolated areas. Clearly, the required change has started with the governmental recognition of the need for renewable technologies and some rules are already in place [15]. However, the implementation of small-scale technologies based on local resources considering local knowledge does not per se guarantee overcoming current challenges.

Balancing causal loops previously analysed considered elements included in the actual rural electrification initiative and in the Social Technology concept. All of them include the Gap in Electricity Access. As a result, they cannot provide suggestions on specific actions to accelerate the process to achieve universal access in Brazil. Yet, they provided important insight for our analysis. We have seen that the influence of traditional practices such as the extension of the grid and the use of imported diesel fuel, have created a very rigid structure in the Amazon region, highly resistant to change. To compensate such a rigid structure, the motivation for action must come from loops that are not directly connected to the gap in electricity access [42]. Such a loop is presented in next section and provides the basis for the identification of concrete actions towards universalization in the Amazon.

\section{ELECTRICITY ACCESS AND SOCIAL TECHNOLOGY: CONCRETE ACTIONS TOWARDS UNIVERSALIZATION IN THE BRAZILIAN AMAZON}

Figure 7 illustrates reinforcing forces corresponding to the Institutions category. It comprises two reinforcing loops which are of particular significance as they can motivate actions towards universalization goals. Remarkably, the figure mainly includes elements of Social Technology: Local knowledge, Participatory Processes, Innovative Practices and, 
Autonomous Communities, which are connected to Implementing Institutions, an important element of the actual Brazilian rural electrification initiative.

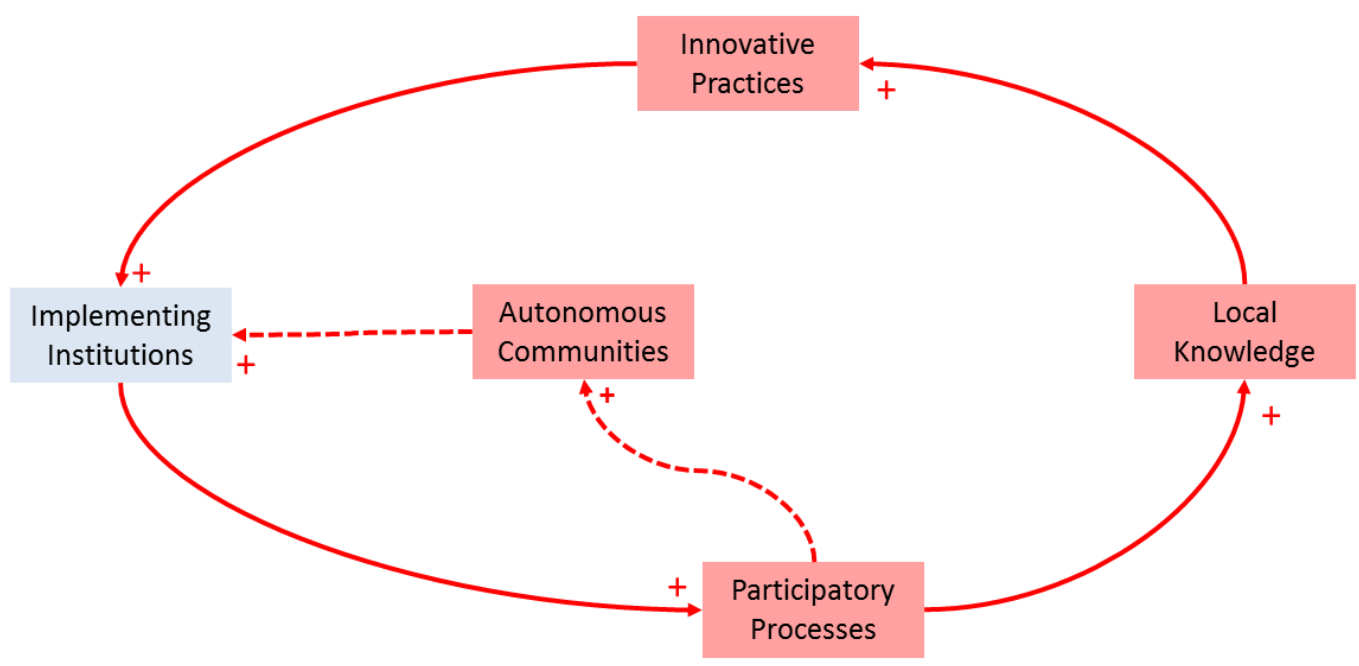

Figure 7. Reinforcing Force corresponding to Institutions category

Once again, Local Knowledge appears as one of the key elements of the system. Figure 7 shows that this element can influence Implementing Institutions based on Participatory Processes, via Innovative Practices. We have seen that the actual rural electrification initiative strongly relies on a centralized approach led by concessionaires on the implementation side. Figure 7 suggests that implementing institutions should adapt to local realities and knowledge. On the one hand, the adaptation process of these institutions has to face three important obstacles: (i) knowledge is dynamic, (ii) knowledge tends to be heterogeneous among local communities, and (iii) the inclusion of local knowledge in natural resources management is at an early stage and needs to be developed further [43]. On the other hand, there is already an important body of local knowledge based in the region which is generally unwritten and often preserved unsystematically which makes it useless for policy makers, planners or potential implementers. Lack of systematized local knowledge can prevent agreements among the agents who make up the system and threaten potential solutions. In the Brazilian Amazon, knowledge held by different agents has not been gathered and managed to support decision-making and planning of rural electrification programs. For example, a recent experience in the state of Pará led to unexpected results as the oil seed that was projected to be used to produce biodiesel was instead sold by the natives to the pharmaceutical industry. The view of rural communities was that the seed was more valuable as a raw material to be sold to the industry than as an energy resource. Clearly, project leaders had another view and did not consider local knowledge during the design of the project ${ }^{5}$.

The development of local knowledge systematization practices could be perceived as a slow process and it is important to remember that in this case, Local Knowledge is part of a reinforcing loop, that is, it could also foster a significant growth of the system. If this condition is not recognized, it could lead to late reactions.

\footnotetext{
${ }^{5}$ Oral information provided by Prof. G. Rendeiro, Senior Researcher in Bioenergy Technology at Universidade Federal do Pará, during a field-visit of the author to Belém do Pará in 2011. The authors have no knowledge of written records on this project.
} 
In this context, the current Brazilian rural electrification initiative lacks concrete actions to use and promote the systematization of existing local knowledge other than that related to the extension of the grid. So far, contact between rural electrification implementers, in this case concessionaires and communities, has been limited to the identification of the demand for electricity services [3]. This has been crucial for incorporating local energy needs into the planning and decision making processes at concessionaire levels but wide local knowledge on indigenous energy resources and the way they could be used has not been explored yet.

Sharing existing knowledge among very disparate actors implies not only systematization but also the establishment of communication channels and methods that enable people to optimize the use of their knowledge, promote collaborative efforts, and provide support to decision makers. Newspapers, radio, books, the Internet, and training workshops are good examples of communication channels. Information and Communication Technologies (ICTs) have proven effective to incorporate the existing knowledge within the community, their values or their culture. Previous experiences in Bolivia, Perú, Ecuador and Uganda are good examples of the use of ICTs as tools not only for systematizing but also for sharing and building knowledge. Rural communities in those countries have used self-managed audio-visual documentation, online agricultural information systems, websites and tele-centres and photographic documentation as communication channels for raising awareness about their activities with the help of radio, cell phones, the Internet and other technical supports [44]. Nevertheless, conversation and discussion, that is, inter-personal communication has played an essential role to achieve effective communication in rural communities where electricity is not yet available [45]. Ideally, communities should discuss the problems facing their particular interests and the information needed to support action and establish rules to solve the identified problems [46]. Other agents involved in the electrification process should also contribute to the discussion. However, they have different interests that are not only dynamic but sometimes contradictory and there is evidence on the fact that their capacity to articulate and enforce consistent rules to achieve common objectives is frequently limited [47]. Thus, appropriate communication channels must be established not only to develop effective knowledge basis but also to facilitate the required agreements and build up a complex set of rules that is unavoidably linked to the implementation of rural electrification projects.

Implementing and promoting appropriate communication channels imply serious challenges particularly within a context such as the Amazon region in which diversity is the norm. A significant number of institutions which are active in rural areas tend to favour hierarchical and undifferentiated communication to rural beneficiaries of different services [48]. Also, the working environment in public agencies often does not allow communication skills to be developed or implemented. Further, long distances make face-to-face communication difficult [48]. Consequently, it is central to identify what kind of information needs to be communicated and who the participants in the process are in order to propose strategies for the creation of particular communication channels that benefit all of them. A number of common practices and tools are already available for this purpose. Interactive maps, Geographical Information Systems (GIS) and content management systems are some of the possible ways to map, collect, present and analyse local knowledge [49, 50]. For example, GIS can be used to integrate local knowledge and renewable resources into the rural electrification program enabling its systematic evaluation across communities, companies, academia and NGOs.

There are also a number of methodologies for formally representing qualitative knowledge. For instance, Dixon et al. (2001) have created a methodology to acquire and represent knowledge from communities living in rural areas. The methodology has been 
used in Africa, Asia and Latin America and it is based on the premise that most knowledge can be broken down into short statements and associated taxonomies of the terms that are used in them. These can then be represented on a computer as a knowledge base using a formal grammar and a series of hierarchies of terms. Connections amongst statements can be explored by viewing sets of related statements as diagrams [51]. In other contexts, mathematical models have demonstrated the convenience of using software tools to find solutions to cases of public infrastructure that had remained unresolved for a number of years [52].

In short, the transition to a more local-knowledge-driven system is directly connected to the ability of institutions to engage in continuous participatory processes. Figure 7 shows that as Participatory processes are enhanced, Local knowledge will help to reinforce Innovative practices that will definitively have a positive effect on Implementing Institutions. Participatory processes facilitate communication among communities, formal and informal organizations and public institutions and enhance their interaction in such a way that they turn their knowledge into a valuable resource for all participants and provide an opportunity to design innovative solutions. For that, it is crucial to agree on what is important to know, communicate and share in order to achieve the common goal of electricity access. How can this information be systematized? What are the challenges in terms of technology and resources? What knowledge and experiences are relevant for the process? Local actors interacting through participatory activities are central and transversal to find possible answers to these questions. Participatory processes link resources, technology, and knowledge to actions. As a result, actions are more likely to be effective if all the agents in a community develop a clear and common understanding of their needs and possible solutions. In such a way, the involvement of all the stakeholders in the process of providing electricity access allows the appropriation of local knowledge and the encouragement of new institutional models in which organizations and individuals who have acted informally can be integrated.

\section{CONCLUDING REMARKS}

The Brazilian rural electrification achievements are connected to an important socio-economic transformation. Social inclusion goals have been incorporated into the national electrification policy and there is already evidence of the effectiveness of this policy to foster development, despite a plausible time lag between the electricity provision and the social impacts inherent to development $[3,53]$. However, the rural electrification initiative has been developed under a very centralized scheme in which local realities have been left aside and not been systematically addressed. There is a need for improved institutions and a better use of energy resources and technologies.

The concept of Social Technology incorporates a new way of conceiving how the relationships between institutions, resources and technology could evolve in the Amazon region. It considers local realities and active participation of a number of agents such as the state, the community, the academia and social movements. This analysis has shown that Social Technology principles can help to identify concrete actions and provide effective responses to the actual shortcoming that the Brazilian rural electrification initiative is facing. There is already a strong political will towards a social transformation that has led to significant development achievements and this could be the first step towards the adoption of Social Technology premises. Yet, additional and significant efforts are required to incorporate the Social Technology concept to the program.

Based on the CLD analysis, an extensive literature review and the collection of in-situ evidence in the form of structured observations and semi-structured interviews [7], we argue that (i) there is a need for systematizing existent local-based knowledge in order to 
create a formalized and common understanding basis to face current electrification challenges in the Amazon and (ii) it is also necessary to establish effective communication systems in order to share that knowledge and effectively design, install and operate renewable and small-scale energy technologies. Figure 8 presents these two concrete actions in relation to the Social Technology concept.

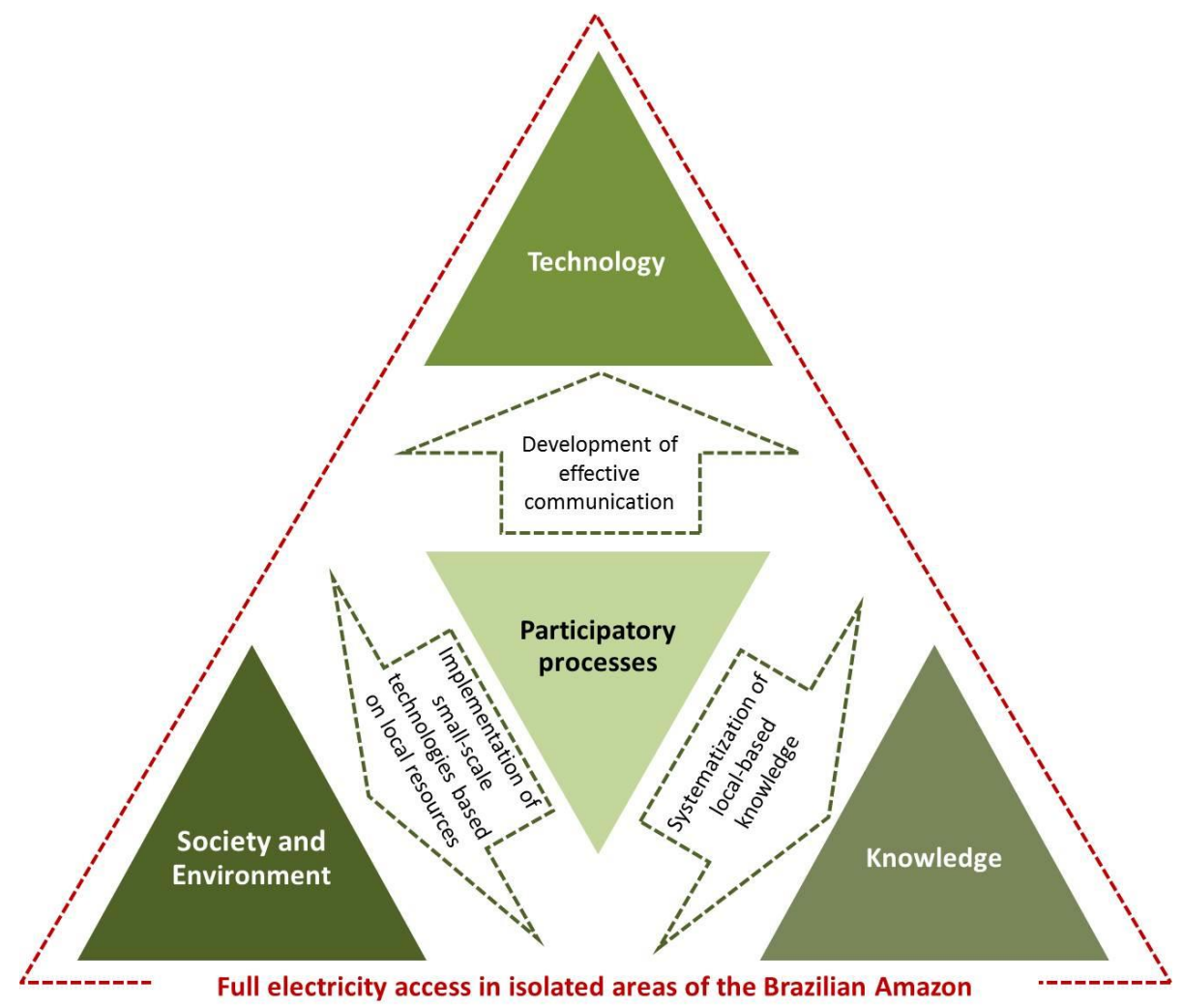

Figure 8. Actions to integrate off-grid technologies to the current rural electrification initiative

The number and the diversity of the involved agents imply complex interconnections and entail significant coordination to propose effective solutions. A new model in which local institutions and communities are better placed to share their knowledge is required. However, the model implies the involvement of new actors who have a better knowledge of local conditions and this adds to the complexity of the system. As a result, participatory activities emerge as crucial and transversal elements fostering possible solutions and providing the means to put in place the required actions. The Social Technology concept has the potential to enhance the identification of concrete actions to overcome the challenges that Brazil is facing in connection to its rural electrification initiative.

Now, the time has come for a more robust involvement of local communities, academia, NGOs, and private entrepreneurs within the rural electrification initiative. All these agents can contribute with their particular knowledge to materialize a well-structured rural electrification program with tangible solutions for the isolated areas of the Amazon region. Giving voice to those who need the solutions and have deep knowledge of their own reality is of paramount importance to put in place innovative practices. Yet, the role of the government at central and local levels is still decisive to create the appropriate environment to materialize this transformation. 


\section{ACKNOWLEDGEMENTS}

This paper was written as part of a research program on Global Energy and Climate Studies funded by the Swedish Energy Agency. The authors are grateful to the Nordic Consortium for Systems Analysis (NORCOSA) and the Swedish IIASA committee at FORMAS for encouraging valuable conceptual discussions of systems analysis methodologies and practical applications.

\section{Nomenclature}

$\begin{array}{ll}\text { ATM } & \text { Appropriate Technology Movement } \\ \text { BTS } & \text { Bank of Social Technologies } \\ \text { CBRTS } & \text { Brazilian Reference Center on Social Technology } \\ \text { CLD } & \text { Causal Loop Diagram } \\ \text { DESA } & \begin{array}{l}\text { Department of Economic and Social Affairs of the United Nations } \\ \text { Secretariat }\end{array} \\ \text { FAO } & \text { Food and Agriculture Organization of the United Nations } \\ \text { FBB } & \text { Foundation Bank of Brazil } \\ \text { GIS } & \text { Geographical Information Systems } \\ \text { GNESD } & \text { Global Network on Energy for Sustainable Development } \\ \text { IBGE } & \text { Brazilian Institute of Geography and Statistics } \\ \text { ICT } & \text { Information and Communication Technologies } \\ \text { IEA } & \text { International Energy Agency } \\ \text { ITDG } & \text { Intermediate Technology Development Group } \\ \text { ITS } & \text { Brazilian Social Technology Institute } \\ \text { MME } & \text { Brazilian Ministry of Mines and Energy } \\ \text { NGO } & \text { Non-governmental Organization } \\ \text { RTS } & \text { Brazilian Social Technology Network } \\ \text { Satecs } & \text { Monitoring System of Social Technologies }\end{array}$

\section{REFERENCES}

1. Global Network on Energy for Sustainable Development. Reaching the Millennium Development Goals and beyond - Access to modern forms of energy as a prerequisite. Global Network on Energy for Sustainable Development. s.l. : Global Network on Energy for Sustainable Development, 2007. ISBN 978-87-550-3600-0.

2. United Nations Development Program. World Energy Assessment Overview: 2004 update. United Nations Development Program. [Online] 2004. [Accessed: 12-Dec-2009] http://www.undp.org/energy/weaover2004.htm.

3. Gómez, M. F. and Silveira, S. Rural electrification of the Brazilian Amazon -Achievements and lessons. Energy Policy. 2010, Vol. 38, No.10, pp. 6251-6260, http://dx.doi.org/10.1016/j.enpol.2010.06.013

4. International Energy Agency. Energy for all. Paris : s.n., 2011.

5. Brazilian Institute of Geography and Statistics. Statistics. Brazilian Institute of Geography and Statistics. [Online] 2011. [Accessed: 01-Jan-2012] http://www.ibge.gov.br/home/download/estatistica.shtm.

6. Gómez, M. F. and Silveira, S. Delivering off-grid electricity systems in the Brazilian Amazon. Energy for Sustainable Development. 2012, Vol. 16, No.2, pp. 155-167, http://dx.doi.org/10.1016/j.esd.2012.01.007

7. Gómez, M. F. Electricity access for human development in the Brazilian Amazon. Licenciate thesis. Stockholm : Royal Institute of Technology, 2012. 
8. Silva-Herran, D. and Nakata, T. Design of decentralized energy systems for rural electrification in developing countries considering regional disparity. Applied Energy. 2012, Vol.91, No.1, pp. 130-145, http://dx.doi.org/10.1016/j.apenergy.2011.09.022

9. Foundation Bank of Brazil. Foundation Bank of Brazil. Social Technologies database. [Online] 2012a. [Accessed: 22-May-2012] http://www.fbb.org.br/tecnologiasocial/pesquisar-tecnologias/.

10. Department of Economic and Social Affairs of the United Nations Secretariat. Analysing and Measuring Social Inclusion in a Global Context. [Online] 2010. [Accessed:

27-Feb-2013] http://www.un.org/esa/socdev/publications/measuring-social-inclusion.pdf.

11. Pasternak, A. Global Energy Futures and Human Development: A Framework for Analysis. Springfield: US Department of Energy Report UCRL-ID-140773. Lawrence Livermore National Laboratory, 2000.

12. Brazilian Presidency. LEI $N^{o}$ 10.438, DE 26 DE ABRIL DE 2002. Presidencia da República Casa Civil. [Online] 2002. [Accessed: 20-May-2011] http://www.planalto.gov.br/ccivil_03/leis/2002/L10438.htm.

13. - LEI N ${ }^{\circ} 12.212$ DE 20 DE JANEIRO DE 2010. Presidência da República Casa Civil. [Online] 2010. [Accessed: 20-May-2011] http://www.planalto.gov.br/ccivil_03/_Ato2007-2010/2010/Lei/L12212.htm.

14. Van Els, R. H., et al. The Brazilian experience of rural electrification in the Amazon with decentralized generation - The need to change the paradigm from electrification to development. Renewable and Sustainable Energy Reviews. 2012, Vol. 16, No.3, pp. 1450-1461, http://dx.doi.org/10.1016/j.rser.2011.11.031

15. Brazilian Ministry of Mines and Energy. Manual de projetos especiais. Programa Luz Para Todos. [Online] 2009. [Accessed: 26-Oct-2011] http://luzparatodos.mme.gov.br/luzparatodos/Asp/documentos.asp.

16. Pereira, M., Freitas, M. and Da Silva, N. Rural electrification and energy poverty: Empirical evidences from Brazil. Energy Policy. 2010, Vol. 14, No.4, pp. 1229-1240.

17. Pinho, J. Soluções Energéticas para a Amazônia. Brasília : Ministry of Mines and Energy, 2008.

18. Blanco, C.; Yves, S.; Mesquita, A. Decision support system for micro-hydro power plants in the Amazon region under a sustainable development perspective. Energy for sustainable development. 2008, Vol. 12, No.3, pp. 25-33.

19. Schmid, A. L. and Hoffman, C. A. Replacing diesel by solar in the Amazon: short-term economic feasibility of PV-diesel hybrid systems. Energy Policy. 2004, Vol. 32, No.7, pp. 881-898, http://dx.doi.org/10.1016/S0301-4215(03)00014-4

20. Pinheiro, G., et al. Rural electrification for isolated consumers: Sustainable management model based on residue biomass. Energy Policy. 2011, Vol. 39, No.10, pp. 6211-6219, http://dx.doi.org/10.1016/j.enpol.2011.07.020

21. Henderson, C. R. The Scope of Social Technology. The American Journal of Sociology. 1901, Vol. 6, No.4, pp. 465-486, http://dx.doi.org/10.1086/210992

22. Brazilian Institute of Social Technology. Instituto de Tecnologia Social. [Online] 2011. [Accessed: 19-Nov-2011] http://www.itsbrasil.org.br/.

23. Brazilian Social Technology Network. Brazilian Social Technology Network. [Online] 2011. [Accessed: 24-May-2011] http://www.rts.org.br/.

24. Schumacher, E. F. Small is beautiful: Economics as if People Mattered. New York: Harper \& Row, 1973.

25. Akubue, A. Appropriate Technology for Socioeconomic Development in Third World Countries. The Journal of Technology Studies. 2000, Vol. 26, No.1. pp. 33-43. 
26. Jéquier, N. and Blanc, G. Appropriate Technology Directory. Volumen II. Paris : Organization for Economic Co-operation and Development (OECD), 1984.

27. Smith, A., Fressoli, M. and Thomas, H. Grassroots innovation movements: challenges and contributions. Journal of Cleaner production. 2013, pp. 1-11. In Press, http://dx.doi.org/10.1016/j.jclepro.2012.12.025

28. Practical Action. Practical Action [Online] 2013. [Accessed: 28-Feb-2013] http://practicalaction.org/history.

29. Kaplinsky, R. Schumacher meets Schumpeter: Appropriate technology below the radar. Research Policy. 2011, Vol. 40, No.2, pp. 193-203, http://dx.doi.org/10.1016/j.respol.2010.10.003

30. Dagnino, R., Brandão, F. C. and Novaes, H. T. Sobre o marco analítico.conceitual da tecnología social. Tecnologia Social - Uma estratégia para o desenvolvimento. Rio de Janeiro. : Fundação Banco do Brasil, 2004, pp. 16-64.

31. Ueno, P. H. and Otero, M. R.. Social Technology in Brazil: A ground-based concept. Seventh international conference of the International Society for Third Sector Research (ISTR). Bangkok, Thailand, July 9-12, 2006.

32. Brazilian Institute of Social Technology. Caderno Conhecimento e cidadania. Tecnologia Social. Instituto de Tecnologia Social. [Online] February 2007. [Accessed: 20-Feb-2012] http://www.itsbrasil.org.br/publicacoes/112.

33. - - SATECS UNI. Sistema de Acompanhamento das Tecnologias Sociais. [Online] 2012. [Accessed:

20-Aug-2012] http://satecsuni.itsbrasil.org.br/download/Uma-Metodologia-de-Analise-das-Tecnolog ias-Sociais.pdf.

34. Foundation Bank of Brazil. Foundation Bank of Brazil. [Online] 2012b. [Accessed: 21-May-2012] http://www.fbb.org.br/quem-somos/como-atuamos/\#.

35. Oterloo, A.M.C.. Tecnologia Social e Desenvolvimento Sustentável. In A tecnologia a serviço da inclusão social e como política pública. Brazilian Social Technology Network., 2010, pp.17-24.

36. Edson, R. Analytic Services Inc. Systems Thinking. Applied. A primer. [Online] October 2008.2 [Accessed: http://www.anser.org/docs/systems_thinking_applied.pdf.

37. Sanches-Pereira, A. and Gómez, M. F.. Towards a Cleaner Vehicle Fleet: the Dynamics of the Swedish Biofuel System. 4th International Workshop - Advances in Cleaner Production: Integrating Cleaner Production into Sustainability Strategies.São Paulo, Brazil, May 22-24, 2013.

38. Kirkwood, C. W. System Dynamics Methods: A quick introduction. Tempe : Arizona State University, 1989.

39. Morecroft, J. D.W. A critical review of diagraming tools for conceptualizing feedback system models. System Dynamics Society. Dynamica Digital Archive. [Online] 1982. [Accessed: http://www.systemdynamics.org/dynamica/articles/81/5.pdf.

04-March-2013]

40. Richardson, G. P. Problems with causal-loop diagrams. Systems Dynamics Review. 1986, Vol. 2, No.2, pp. 158-170. Article first published online : 22 DEC 2006.

41. Sterman, J. Business Dynamics: Systems Thinking and Modeling for a Complex World. Irwin : McGraw-Hill, 2000. ISBN: $9780072389159 .$.

42. Bellinger, G. Mental Model Musings. [Online] 2004. [Accessed: 28-Dec-2012] http://www.systems-thinking.org/.

43. Pinedo-Vasquez, M., Ruffino, L. M. and Padoch, C. Amazon Várzea: the Decade Past and the Decade Ahead. New York : Springer, 2011, http://dx.doi.org/10.1007/978-94-007-0146-5 
44. Burch, S. Which knowledge for rural development? [ed.] S. Bursh. Knowledge sharing for rural development: challenges, experiences and methods. Quito : Latin American Information Agency, 2007, pp. 5 - 12.

45. Siegel, J. R. and Rahman, A. The Diffusion of Off-Grid Solar Photovoltaic Technology in Rural Bangladesh. Tuffts University. The Center for International Environment \& Resource Policy. [Online] September 2011. [Accessed: 27-Aug-2012] http://fletcher.tufts.edu/CIERP/ /media/Fletcher/Microsites/CIERP/Publications/2011 /SiegelRahman11SepSolarEnergy_Fsin.pdf.

46. Mchombu, K. J. Sharing Knowledge for Community Development and Transformation: A Handbook. Oxfam Canada. [Online] August 2004. [Accessed: 27-Aug-2012] Sharing Knowledge for Community Development and Transformation: A Handbook.

47. Barret, C. B., Lee, D. R. and McPeak, J. G. Institutional Arrangements for Rural Poverty Reduction and Resource Conservation. World Development. 2005, Vol. 33, No.2, pp. 193-197, http://dx.doi.org/10.1016/j.worlddev.2004.07.008

48. Food and Agriculture Organization of the United Nations. Framework on effective rural communication for development. Deutsche Gesellschaft für Internationale Zusammenarbeit (GIZ) GmbH. [Online] 2006. [Accessed: 26-Aug-2012] http://www2.gtz.de/dokumente/bib/07-0218.pdf.

49. Rantanen, H. Managing and mapping local knowledge in urban planning. ENHR 2007 International Conference: Sustainable Urban Areas. Delft, The Netherlands, June 25-28, 2007.

50. Adinarayana, J., Azmi, S., Tewari, G. and Sudharsan, D.. GramyaVikas: A distributed collaboration model for rural development planning. Computers and Electronics in Agriculture. 2008, Vol. 62, No.2, pp. 128-140, http://dx.doi.org/10.1016/j.compag.2007.12.008

51. Dixon, H. J., Doores, J.w., Joshi, L. and Sinclair, F.L.. The Agroecological Knowledge Toolkit. School of Agricultural and Forest Sciences, University of Wales, Bangor. Agroecological Knowledge toolkit for windows: methodological guidelines, computer software and manual for AKT5. [Online] 2001. [Accessed: 17-Aug-2012] http://akt.bangor.ac.uk/documents/forewordandtableofcontents.pdf.

52. Danielson, M., Ekemberg, L. and Aron Larsson, J. I. Using a Software Tool for Public Decision Analysis: The Case of Nacka Municipality. Decision Analysis. June 2007, Vol. 4, No.2, pp. 76-90, http://dx.doi.org/10.1287/deca.1070.0088

53. Zaytecbrasil Serviços de Pesquisa. Quantitative Research on Household Satisfaction Evaluation and Impact of LPT Program. [Online] 2009. [Accessed: 19-Jan-2009] http://luzparatodos.mme.gov.br/luzparatodos/downloads/Resultado_Pesquisa_2009_n acional.pdf. 